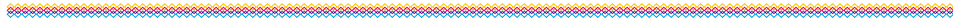

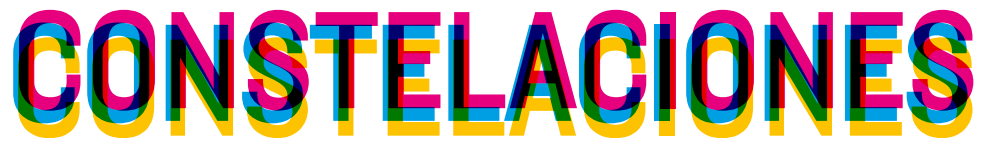

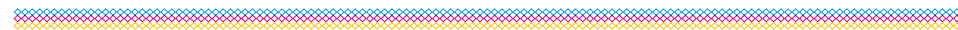




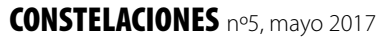

Revista de Arquitectura de la Universidad CEU San Pablo

Architecture Magazine of CEU San Pablo University

Periodicidad anual

Annual periodicity

COMITÉ DE REDACCIÓN EDITORIAL COMMITTEE

\section{Dirección Directors}

Juan García Millán

Santiago de Molina

Jefa de Redacción Editor in Chief

Covadonga Lorenzo Cueva

Secretario de Redacción Editorial Clerk

Rodrigo Núñez Carrasco

Maquetación y producción Design and production

María Fernández Hernández

Clara Martínez-Conde Rubio

Revisión de textos en inglés English Editing

Carlota Sáenz de Tejada Granados

Responsable Web Web Page Manager

María Isabel Castilla Heredia

Diseño Original Original Design

Juan Roldán Martín

\section{Vocales Board Members}

María Dolores Gómez Pulido. Escuela Politécnica Superior, Universidad CEU San Pablo, Madrid

Rocío Carvajal Alcaide. Escuela Politécnica Superior, Universidad CEU San Pablo, Madrid

Clara Eugenia Maestre Galindo. Escuela Politécnica Superior, Universidad CEU San Pablo, Madrid

\section{CONSEJO EDITORIAL EDITORIAL BOARD}

Beatriz Colomina. School of Architecture, Princeton University, New Jersey

Carmen Díez Medina. Escuela de Ingeniería y Arquitectura, Universidad de Zaragoza

María Antonia Frías Sargadoy. Escuela Técnica Superior de Arquitectura, Universidad de Navarra

Juan Miguel Hernández Léon. Escuela Técnica Superior de Arquitectura, Universidad Politécnica de Madrid

Juan José Lahuerta Alsina. Escuela Técnica Superior de Arquitectura, Universidad Politécnica de Cataluña, Barcelona

Eduardo Leira Sánchez. Ex director del Plan General de Ordenación Urbana, Madrid

Joaquín Medina Wamburg. Facultad de Aquitectura Diseño y Urbanismo, Universidad de Buenos Aires

Zaida Muxí Martínez. Escuela Técnica Superior de Arquitectura, Universidad Politécnica de Cataluña, Barcelona José Joaquín Parra Bañón. Escuela Técnica Superior de Arquitectura, Universidad de Sevilla

Víctor Pérez Escolano. Escuela Técnica Superior de Arquitectura, Universidad de Sevilla

Fernando Pérez Oyarzún. Escuela de Arquitectura y Diseño, Pontificia Universidad Católica, Santiago de Chile Judith Sheine. School of Architecture and Allied Arts, University of Oregon, Portland

Andrés Walliser Martínez. Global Design, New York University, Nueva York

\section{ISSN 2340-177X}

Depósito legal M-13872-2013

(c) de los textos, sus autores

(c) de las imágenes autorizadas

(C) Revista Constelaciones

๑) Escuela Politécnica Superior, Universidad CEU San Pablo

Universidad CEU San Pablo

Escuela Politécnica Superior

Urbanización Montepríncipe, s/n

Alcorcón, 28925. Madrid (España)

constelaciones@eps.ceu.es

www.uspceu.es

www.revistaconstelaciones.wordpress.com

Edición Edition

Fundación Universitaria San Pablo CEU

Madrid, España

Impresión Printing

VA Impresores

Impreso en España Printed in Spain

Distribución Distribution

CEU Ediciones

\author{
INDEXACIÓN INDEXING \\ Índices Index \\ Latindex \\ Avery Index \\ ErihPlus \\ MIAR
}

Bases de datos Data bases

Dialnet

Índices en evaluación Evaluation Index

Web of Science

Scopus

Dulcinea

EBSCO

Sherpa Romeo
Los textos que componen Constelaciones se obtienen mediante convocatoria pública. Para que los trabajos recibidos entren en el proceso de selección de los artículos a publicar deben ser trabajos originales no publicados anteriormene, con una extensión recomendada de 3.000 palabras, título, resumen (un máximo de 150 palabras) y palabras clave (un mínimo de cuatro palabras), en español y en inglés. Tras haber cumplido estos requisitos (y los correspondientes incluidos en las normas editoriales de la revista, disponibles para consulta en formato digital desde el comienzo de la convocatoria), tiene lugar un proceso de revisión y evaluación de los artículos previa aceptación de los mismos para su publicación. Para acometer dicho proceso, y con el fin de asegurar la calidad de los contenidos, la revista Constelaciones recurre a evaluadores externos a la institución editora y anónimos (cada artículo es evaluado por dos de ellos) encargados de someter a crítica los mismos. Todos los artículos de investigación publicados en esta revista han pasado por dicho proceso. La recepción de artículos se extendió hasta el 30 de septiembre de 2016. Texts included in Constelaciones are obtained by public announcement. Only original papers that have not been previously published will be included in the process of selection of articles. They should not exceed 3.000 words and should include a title, an abstract (no more than 150 words) and keywords (a minimum of four words), in Spanish and English. After having fulfilled these requirements (and those included in magazine editorial standards, available for consultation from the beginning of the Call for Papers), occurs a process of review and evaluation of articles upon acceptance of them for publication. To undertake this process, and in order to ensure the quality of the contents, Constelaciones turns to external and anonymous evaluators to the institution (each article is evaluated by two of them) responsible for the critic. All the articles published in this journal have undergone this process. The deadline for reception was extended until September 30, 2015.

Todos los derechos reservados. Esta publicación no puede ser reproducida, ni en todo ni en parte, ni registrada, ni transmitida, ni almacenada en ninguna forma ni por ningún medio, sin la autorización previa y por escrito del equipo editorial. En este número se han utilizado algunas imágenes de las que no se ha podido identificar al propietario de los derechos. En estos casos hemos entendido que las imágenes son de libre uso. En caso de identificar alguna de estas imágenes como propia, por favor, póngase en contacto con la redacción de Constelaciones. Los criterios expuestos en los diversos artículos de la revista son responsabilidad exclusiva de sus autores y no reflejan necesariamente los que pueda tener el equipo editoral. El equipo editorial de la revista no se responsabiliza de devolver la información enviada a la redacción a no ser que se le solicite expresamente. All rights reserved. This publication cannot be reproduced, in whole or in part, nor registered, transmitted or stored in any form or by any means, without the written permission of the Editorial team. In this issue some images were used without knowing the owner of the rights. In these cases, we have understood that the images are free of use. In case you identify written permission of the Editorial team. In this issue some images were used without knowing the owner of the rights. In these cases, we have understood that the images are free of use. In case you identify
any of these images as your own, please, contact with the Editorial staff of Constelaciones. The opinions expressed in this issues's articles are entirely the responsibility of their authors and are not necessarily shared by the editors of this journal. The publisher don't take responsibility for returning submitted material which is not expressly requested. 

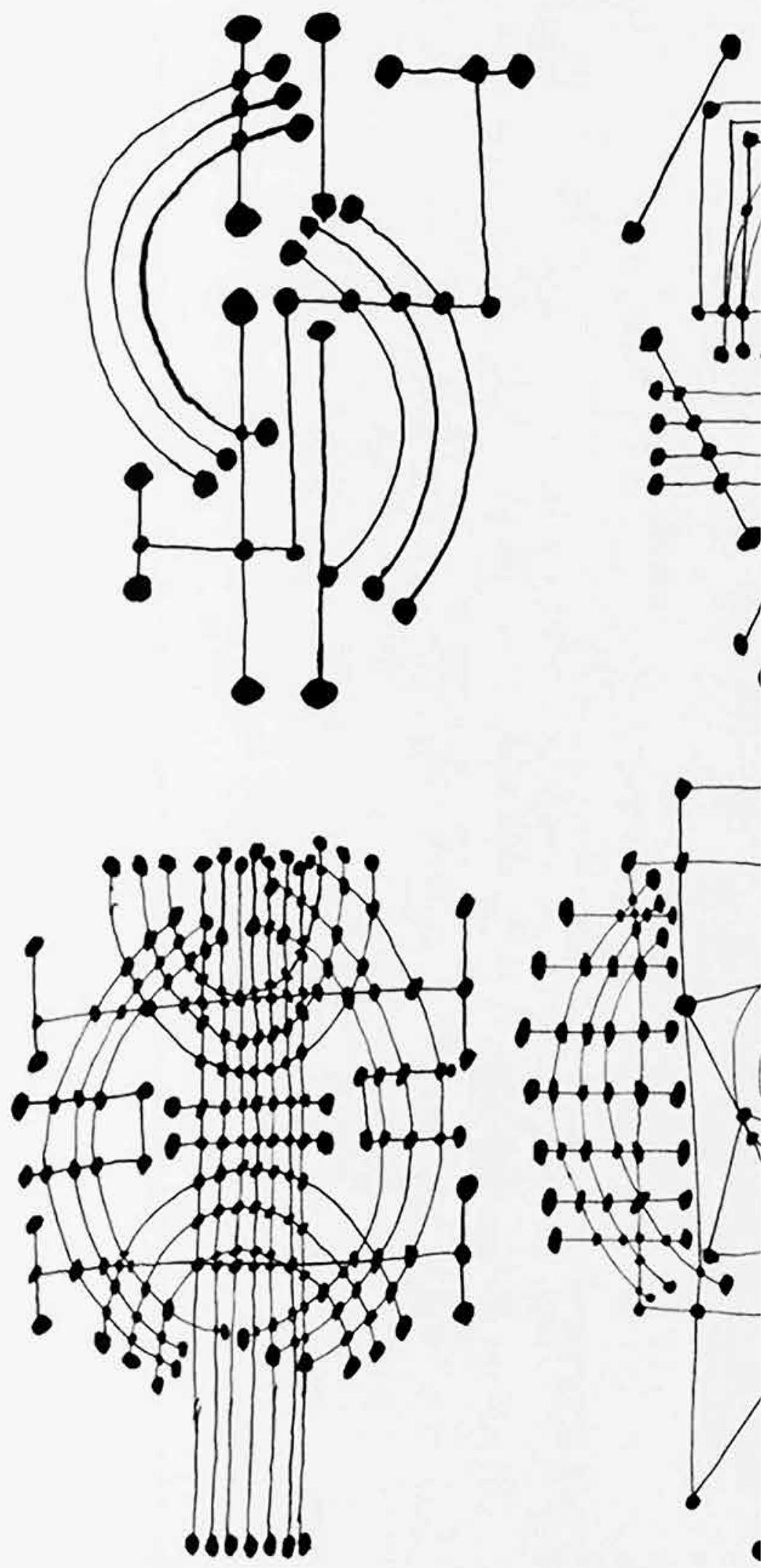


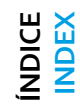

จ

ก)

品

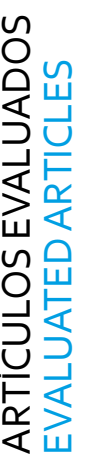

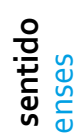

बํำ

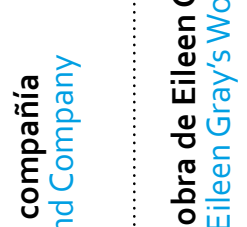

드.

ฮั

茄

:

ที่ ปั อ

苦云

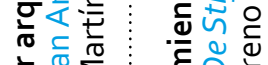

过

ह $\frac{2}{3}$

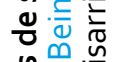

눈

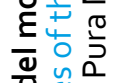

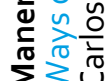

นับ

음

๗ั

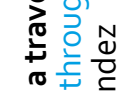

号

궁워

뜬

원

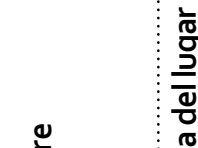

임

ส

응

离

$: \frac{\mathscr{2}}{ \pm}$

을

tั

ग

ํํำ

ํㅡㄹ

:

응 $\frac{\cup}{0}$

บับ

인

든

冚

号京

ब

ฮั

을

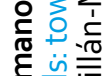

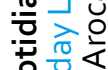

언

으 $\frac{\pi}{\pi}$

产

등 똥

告崖

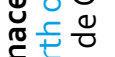

ํํㄴ

일

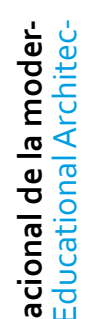

高
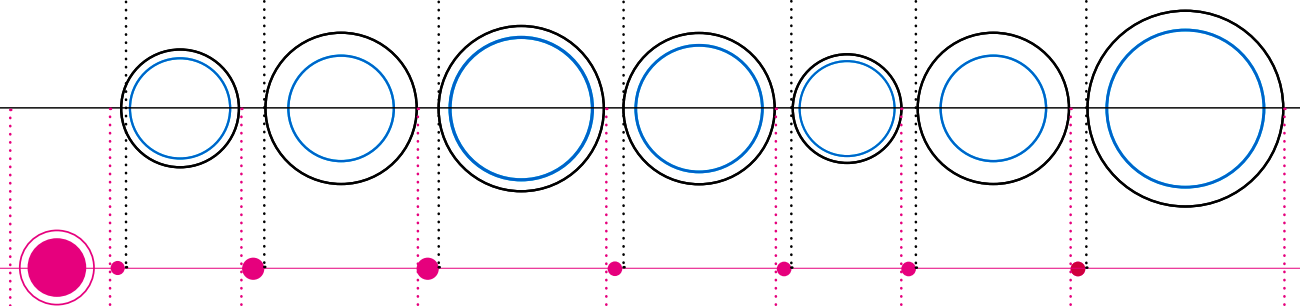

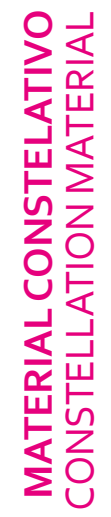

岂㟧

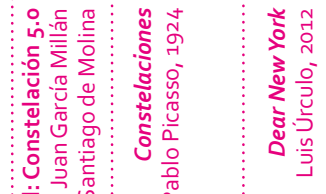

$=\quad \stackrel{m}{\sim}$

$\stackrel{\bullet}{v}$
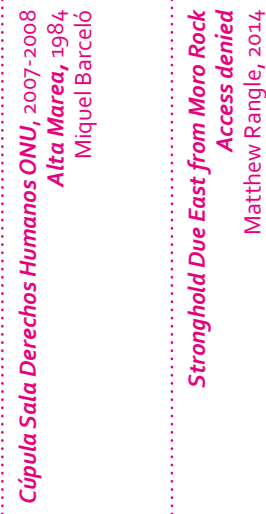

$\overline{6}: \AA$

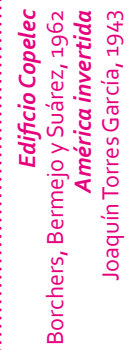

$\infty$

응 


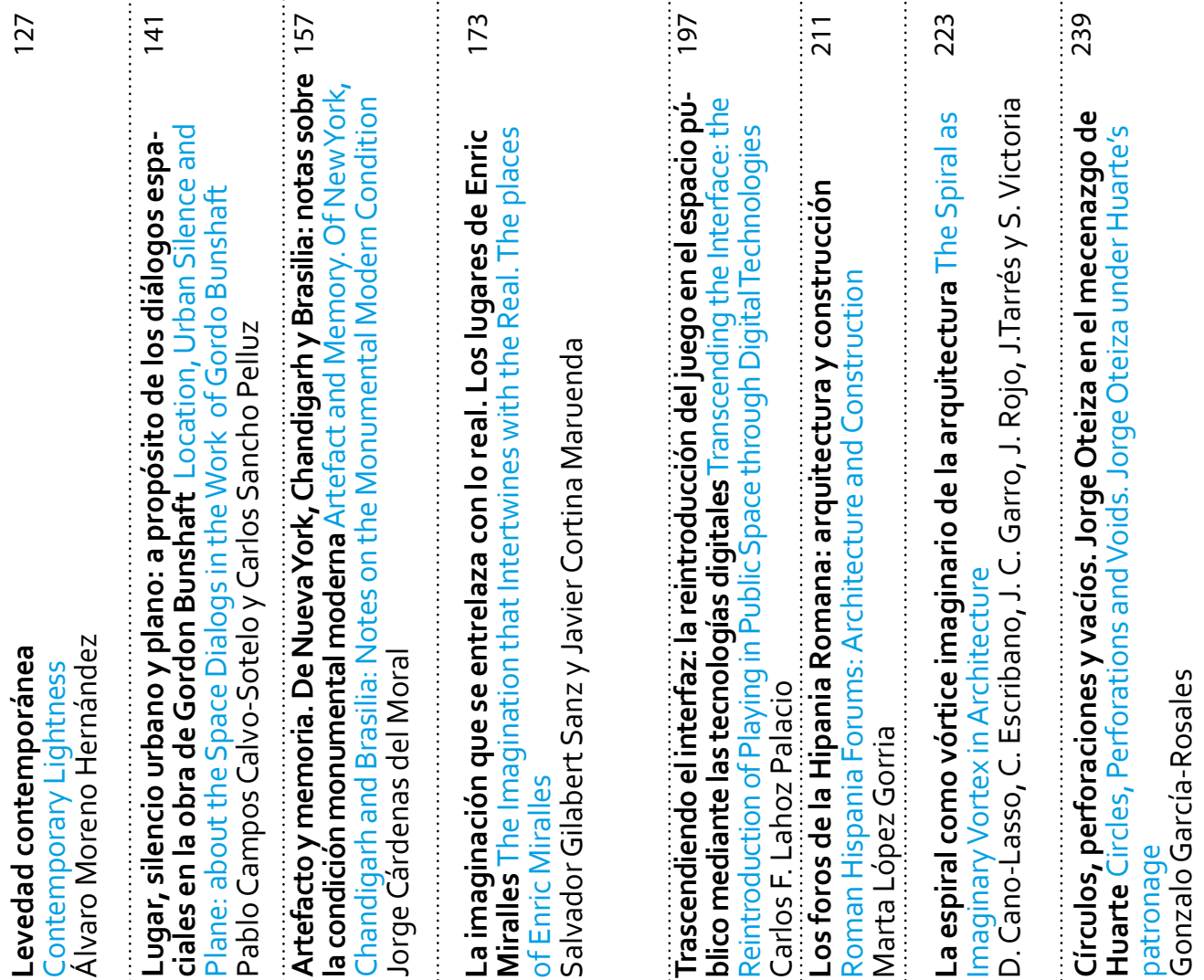
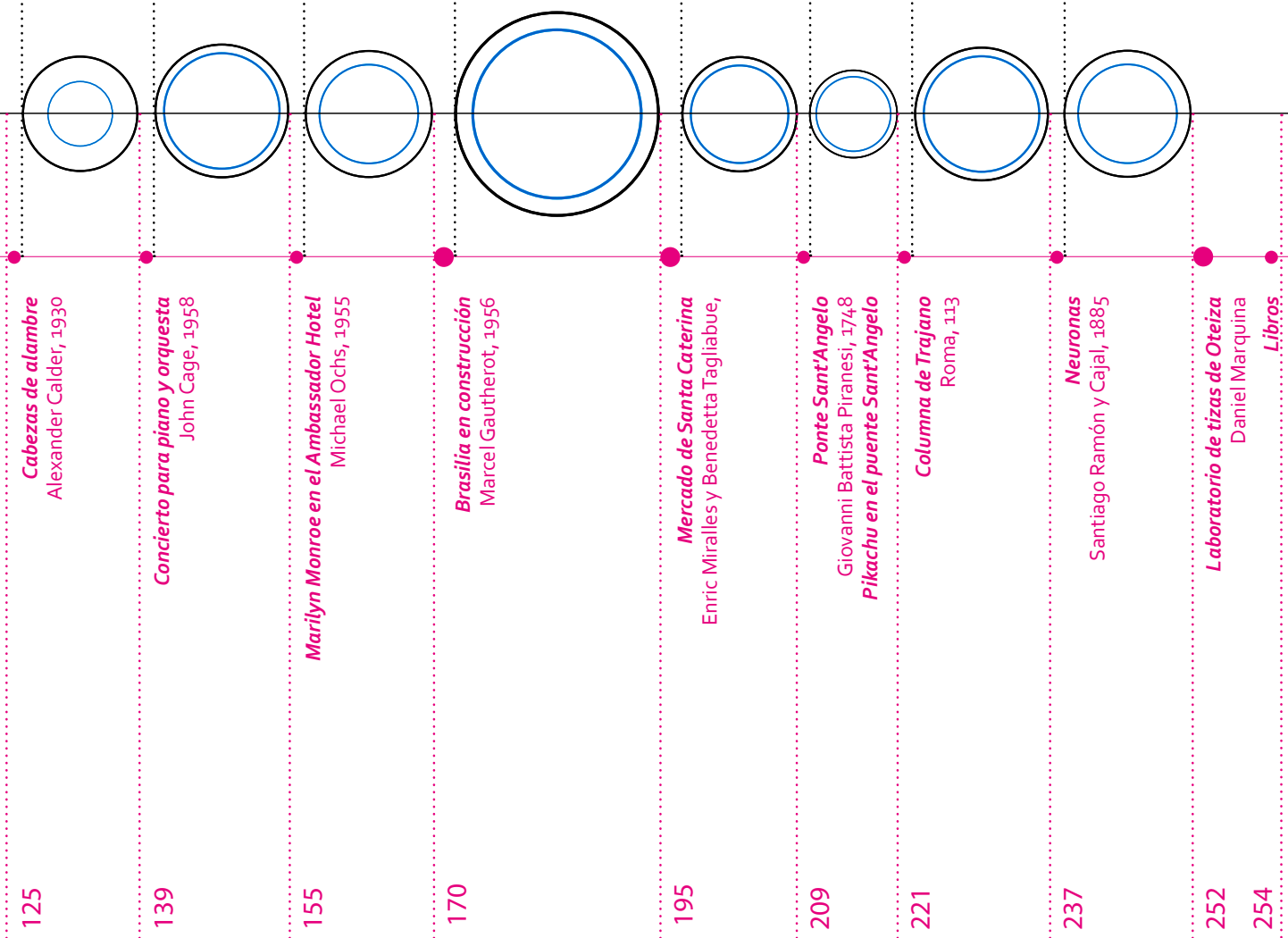


\title{
Lugar, silencio urbano y plano: a propósito de los diálogos espaciales en la obra de Gordon Bunshaft Location, Urban Silence and
} Plane: about the Space Dialogs in the Work of Gordon Bunshaft

\author{
Pablo Campos Calvo-Sotelo y Carlos Sancho Pelluz \\ Escuela Politécnica Superior, Universidad CEU San Pablo, Madrid \\ Traducción Translation Miguel Ángel Fernández Escárzaga
}

Palabras clave Keywords

Gordon Bunshaft, Lever House, silencio urbano, desplazamiento, desmaterialización, normativas urbanísticas, lugar Gordon Bunshaft, Lever House, urban silence, displacement, dematerialization, planning regulations, place

\section{Resumen}

En la relación de la Arquitectura contemporánea con el lugar, el silencio urbano se percibe como parte integrante de una secuencia continua perteneciente al paisaje construido. Bajo este enfoque, el presente artículo analiza tres obras de Gordon Bunshaft, las cuales ilustran diversos tipos de relación dialógica entre el proyecto espacial y las preexistencias: la Lever House, el Edifico Pepsi-Cola y la ampliación de la Albright Knox Art Gallery, todas ellas en el área metropolitana y el Estado de Nueva York. Sus respectivas resoluciones arquitectónicas manifiestan sensible y sutilmente el silencio urbano como elemento compositivo, en forma de ámbito intersticial situado entre el nuevo objeto ideado y el lugar donde se integra. Esta estrategia dialógica se traduce esencialmente a dos tipologías de configuración: en primer lugar, el desplazamiento y giro del plano vertical de la pieza arquitectónica con respecto a la línea de fachada urbana y en segundo, la desmaterialización volumétrica en el plano horizontal inferior, resuelta en clave de continuidad espacial respecto al contexto ciudadano.

\section{Abstract}

In the relationship of contemporary Architecture with place, urban silence is perceived as an integral part of a continuing sequence embedded in the built landscape. Under this approach, this paper discusses three works by Gordon Bunshaft, which illustrate different types of dialogic relationship between the spatial project and pre-existences: Lever House, the PepsiCola Building and the addition to the Albright Knox Art Gallery, all of which are located in the metropolitan area of New York State. Their respective architectural resolutions sensitively and subtly express urban silence as a compositional element, in the form of an interstitial space between the new created object and the place in which it is embedded. This dialogic strategy essentially translates into two kinds of configuration: first, the displacement and rotation of the vertical plane of the architectural piece with respect to the urban façade line and secondly, vol umetric dematerialisation in the lower horizontal plane, resolved with spatial continuity with respect to the civic context. 
Acerca del silencio como diálogo en el arte y la arquitectura. "El espacio está creado como una relación entre objetos. Estas relaciones persisten en la experiencia perceptiva, aunque el hombre de la calle no pueda reconocerlas de forma espontánea [...] El espacio entre las cosas no parece simplemente vacío". (1) Con estas palabras de Rudolf Arnheim se introduce el concepto de relación dialógica entre pieza arquitectónica y lugar que plantea Gordon Bunshaft en sus obras más significativas, que lo catapultaron como uno de los maestros de la arquitectura del siglo xx: la Lever House, el Edificio Pepsi-Cola o la ampliación de la Albright Knox Art Gallery.

Como introducción temática en clave de analogía con otras formas de composición artística, debe subrayarse la potencial naturaleza intrínsecamente incompleta de toda obra artístico-arquitectónica, susceptible de culminar su significado mediante la relación dialógica con el observador. "Lo que se transmite en arte no es una enseñanza ni un contenido específico, sino una elaboración que compromete al espectador a sentir y actuar, a configurar y completar la obra, pues el arte transmite también la conmoción, la naturaleza incompleta del conocimiento -el no saber- que convierte a las obras en perpetuas incógnitas". (2) La relación, pues, entre obra de arte y observador implica valorarla en términos de contemplación e introspección, lo que conduce a su vez a la noción de 'poética del silencio', como algún trabajo ha identificado con acierto en la producción de diversos artistas y arquitectos, como Mies Van der Rohe. (3)

En referencia al compromiso del arte con la misión de provocar conmoción, cabe explorar el mundo de la música. Toda melodía se compone de notas que se ensamblan en resultados armónicos para el oído; algo semejable acontece en la esfera de la arquitectura, cuyas piezas construyen paulatinamente entornos urbanísticos ordenados, estimulando fecundas relaciones dialógicas con sus usuarios en clave de percepción psicológica. Paralelamente, dichas realidades arquitectónicas articulan diálogos que enlazan sociedad y territorio. (4) El silencio musical se comporta

Silence as a Dialogue between Art and Architecture. "The space is created as a relation between objects. These relations persist in perceptual experience, even though the man in the street may not spontaneously acknowledge them [...] Space between things turns out not to look simply empty". (1) This proposition of Rudolph Arnheim's introduces the concept of a dialogic relationship between architectural piece and place which Gordon Bunshaft manifests in his main works -this catapulted him to the forefront of 20th century architecture: Lever House, the Pepsi-Cola Building and the addition to the Albright Knox Art Gallery.

As a thematic lead-in by way of analogy to other forms of artistic composition, we should note that any architectural-artistic work is potentially incomplete in itself, and finds its full meaning only in a dialogic relationship with the observer.

\footnotetext{
"What art conveys is not a teaching or specific content but a form of elaboration that engages the viewer in feeling and taking action, in shaping and completing the work, because art also conveys commotion, the incomplete nature of knowledge -the absence of knowledge- which makes of every work of art a continuing enigma". (2) Hence the relationship between a work of Art and the observer calls into being a meditation in the form of contemplation and introspection, which in turn leads to the notion of a 'poetics of silence', as some scholars have rightly identified in the oeuvre of some artists and architects, such as Mies vand der Rohe. (3)
} 
como una nota más que provoca una sutil y placentera conmoción sensorial. Tal estrategia compositiva puede extrapolarse a la arquitectura; cuando se proyecta un 'silencio' entre un edifico de nueva planta y los actores que configuran las preexistencias, el resultado es un acuerdo dialógico entre determinados elementos a través de un vacío urbano. Así formulado, el 'silencio urbano' no se comporta como una naturaleza muerta, sino como un elemento activo en la composición espacial. Este vínculo del proyecto con el lugar mediante términos relacionales implícitos se contempla muy nítidamente en las referidas tres obras de Bunshaft, donde el acuerdo entre lo nuevo y lo viejo integra dicho 'silencio urbano'.

Regresando a las metáforas compositivas entre música y arquitectura, al hilo de lo que teoriza Arnheim, (5) podría juzgarse a priori que cualquier 'momento' temporal con ausencia de notas está 'vacío'; pero el carácter de estos lapsos (sonoros o espaciales) reviste más riqueza y complejidad estando su corpus intervenido por gradientes. Tales 'momentos' pueden estar privados de sonido o masa, pero no están 'vacíos'. En la esfera urbana, la vivencia del lugar resulta una experiencia eminentemente dinámica. La densidad del 'silencio' intersticial entre volúmenes construidos (como parte componente de la imagen), disminuye en la medida en que aumenta la distancia entre dichos volúmenes, acabando a la postre por disolverse.

La relación de un nuevo proyecto con el lugar, mediante la incorporación dialógica del 'silencio urbano', puede traducirse a dos tipologías, dependiendo de la herramienta compositiva empleada: el desplazamiento y giro del plano vertical, y la desmaterialización del plano horizontal. En el primer caso, la dimensión vertical del plano implicará una proyección más directa de la obra arquitectónica hacia el observador; en el segundo, la componente horizontal enfatizará la cualidad compositiva del volumen global y sus vínculos con los elementos del entorno.

Prompted by the commitment of Art to the mission of provoking a commotion, we might explore the world of Music. A melody is shaped by notes that assemble into a result that is harmonious to the ear. Something of this sort happens also in the domain of Architecture, whose pieces gradually build up an ordered urban environment and stimulate fertile dialogic relations with their users through psychological perception. In parallel to this, those architectural realities articulate dialogues that bond the community to the territory. (4) Musical silence, for its part, acts as another form of musical note, which triggers a pleasurable sensory commotion. This compositional strategy is extensible to Architecture, where a 'silence' is projected between a newly erected building and the actors making up the pre-existing stage: the outcome is a dialogic accord among several elements across an urban vacuum. Thus formulated, 'urban silence' does not behave like a still life; rather, it is an active player in the spatial composition. These ties between project and place by means of implied relations is seen with striking clarity in these three works of Bunshaft, where the concord between the new and the old gives rise to that 'urban silence'.

To return to the compositional analogy between Music and Architecture, as theorised by Arnheim, (5) one might suppose at first that any 'moment' of time in which notes are absent is 'empty'; but the nature of these lapses (aural or spatial) are in fact richer and more complex, and their corpus is complicated by a system of gradients. Those 'moments', though devoid of sound or mass, are by no means 'empty'. In the urban realm, one's lived experience is preeminently dynamic. The density of the interstitial 'silence' between built volumes (as components of the image) decreases in the same measure as the distance between those volumes lengthens: finally, it dissolves. 


\section{Desplazamiento y giro del plano vertical con respecto a la línea de fachada urbana}

una interpretación de la LeVer House. El edificio que se encontraba al otro lado de la calle 53 (en Park Avenue) era el Racquet and Tennis Club. El 'silencio urbano' entre el emergente volumen vertical de la Lever House y dicho club (Fig. 1) adquirió una gran importancia en el resultado final del conjunto, ya que sirvió como estrategia compositiva para alcanzar un sutil equilibrio espacial, cuestión a la que se refiere Carol Krinsky. (6)

La presencia del Racquet and Tennis Club influyó fehacientemente en el diseño de la Lever House. La posición definitiva de la torre no sólo estuvo condicionada por su adaptación al soleamiento, sino por responder espacialmente en clave de dialogía arquitectónica a la preexistente obra de William S. Richardson; ello supuso que la pieza se desplazase en dirección
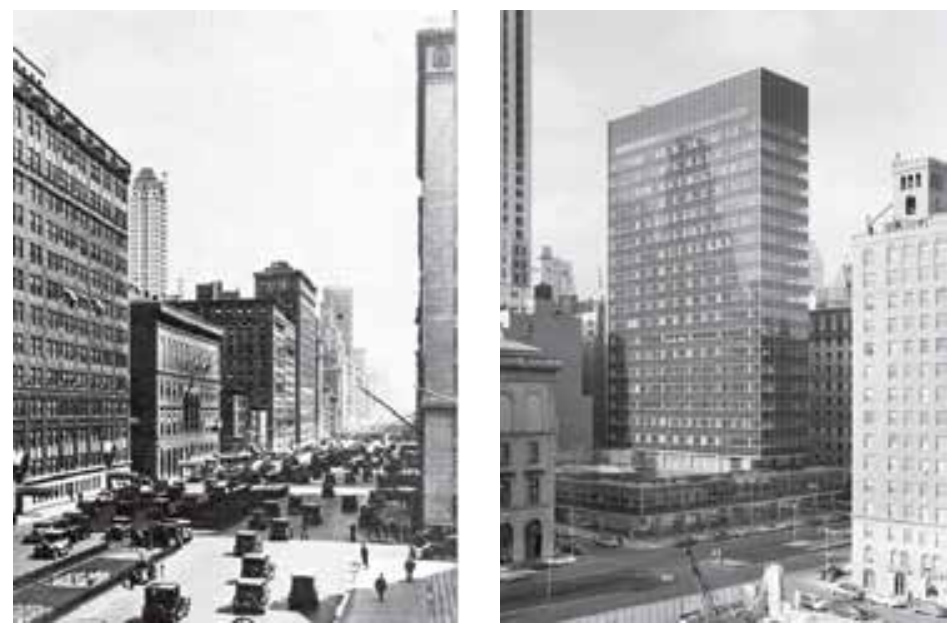

Fig. 1. Racquet and Tennis Club, antes y después de la construcción de la Lever House.

Fig. 2. Hipótesis 1 (gráfico elaborado por los autores).

The relationship of a new project with the place through the dialogic incorporation of 'urban silence' can take two distinct forms, depending on the compositional tool applied: displacement and rotation of the vertical plane and dematerialisation of the horizontal plane. In the first instance, the vertical dimensional of the plane involves a more direct projection of the architectural work toward the observer; in the second instance, the horizontal component emphasises the compositional quality of the overall volume, and its ties to the surrounding shapes.

Displacement and Rotation of the Vertical Plane with respect to the Urban Façade Line

AN INTERPRETATION OF Lever House. The building that stood on the other side of 53rd Street, on Park Avenue, was the Racquet and Tennis Club. The 'urban silence' between the emerging vertical volume of Lever House and the club (Fig. 1) became vital to the final result of the whole, insofar as it served as a compositional strategy to achieve a subtle spatial equilibrium, as noted by Carol Krinsky. (6)

It is a certainty that the presence of the Racquet and Tennis Club influenced the design of Lever House. The final positioning of the tower took account, of course, of adaptation to sunlight, but it was affected just as much by the urge to produce a spatial response in an architectural dialogue with the pre-existing work of William S. Richardson. This meant that the building was displaced in the opposite direction by up to one-third from the facade front, so reaching that alignment with the adjoining building in which Bunshaft was most interested. This endowed the 


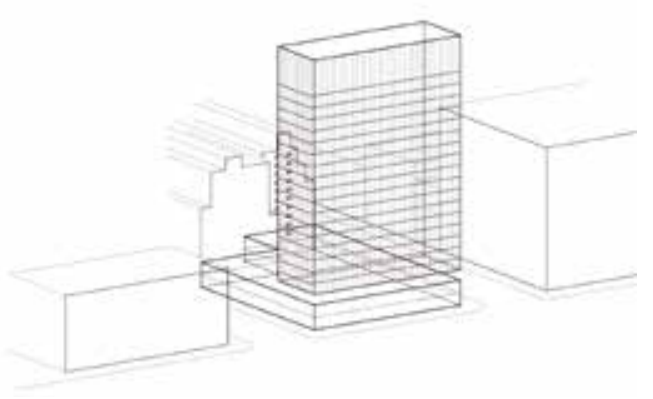

opuesta, hasta un tercio del frente de fachada, alcanzando la línea medianera del edificio colindante que más interesaba a Bunshaft. Esto dotó al conjunto de un equilibrio inteligente, tanto en sí mismo (7) como con el entorno inmediato del que formaría parte. Una operación relativamente comparable con el 'silencio urbano' que generaría el Seagram de Mies Van der Rohe, al otro lado de Park Avenue.

Seguidamente, se analizan cuatro alternativas diferentes que la Lever House podría haber adoptado para la posición de su cuerpo vertical, concluyéndose que la solución realizada fue la más acertada:

a. paralela a Park Avenue y enrasada con la línea de fachada. La primera estrategia proyectual de Bunshaft fue la de plantear un paralelismo entre la torre y Park Avenue, pero pronto reconocería que no era la mejor solución, como explicó años después: "Un día hicimos una maqueta de un volumen alineado a Park Avenue de doce plantas, la mayor altura que nos permitía la normativa si lo enrasábamos con la línea de fachada, pero nos dimos cuenta que el edificio se orientaba hacia los testeros de los edificios vecinos, y esto provocaría una vista desagradable desde el puesto de trabajo y desechamos la idea". (8) Si se hubiera emplazado la torre paralela a la avenida, enrasada con la línea de fachada, (Fig. 2) su imagen
Fig.3. Vuelco visual a modo de 'pescante invertido' (gráfico elaborado por los autores).

whole with an intelligent equilibrium, both in itself (7) and with the immediate environment of which it was to form a part. The approach is relatively comparable to the 'urban silence' created by the Seagram building by Mies van der Rohe on the other side of Park Avenue.

It is time now to discuss four different approaches which could have been adopted for the positioning of the vertical body of Lever House, the conclusion being that the solution arrived was in fact the best:

A. Parallel to Park Avenue and fully aligned with the Streetfront. Bunshaft's initial project design strategy was to establish a parallel alignment between the tower and Park Avenue, but he soon realised this was not the right approach, as he explained years later: "We made a model one day of what you could build by facing a thick twelve-story building on Park Avenue, the greatest height permitted by the planning rules if you matched the streetfront [...] You'd have a space in between, so a lot of people working in the building would be looking at those junky walls. It was not even worth considering". (8) If the tower had in fact been placed parallel to the avenue in line with the street facade, (Fig. 2) its image would have emerged as a giant screen, giving the impression of taking up the entire site. But a twodimensional proposal, in the mode of an elevation plan, would have been a conceptual misstep when compared to a three-dimensional spatial interiorisation, perceptible from a multiplicity of perspectives. If the vertical piece had been placed at the end, the conjunction of the platform and the tower would have been perceived as an 'inverted jib', upsetting the balance and triggering a sense of 'visual thrust' towards the avenue. (Fig. 3) 
habría emergido como una gran pantalla, dando la sensación de ocupar toda la parcela. Sin embargo, habría supuesto un error conceptual plantear la propuesta en clave bidimensional, como si de un alzado se tratara, frente a una interiorización espacial tridimensional, perceptible desde una multiplicidad perspectiva. Al colocar en el extremo la pieza vertical, el conjunto entre la plataforma y la torre se habría leído a modo de 'pescante invertido', carente del adecuado equilibrio, lo que provocaría sensaciones perceptivas de 'vuelco visual' hacia la avenida. (Fig. 3)

B. paralela a Park Avenue y desplazada hasta el fondo de la parCELA. Si se hubiese trasladado la pieza hasta el fondo, la imagen recordaría a la torre-plataforma que realizó Nathaniel A. Owings (Tomorrow's Office Building). Se conseguiría tapar los testeros de los edificios vecinos, (Fig. 4) pero siendo un solar en forma de L, la línea del muro medianero del edificio ubicado en la calle 53 no estaría alineado con la del emplazado en la calle 54. El consiguiente problema es que el cuerpo vertical se desplazaría hasta la línea
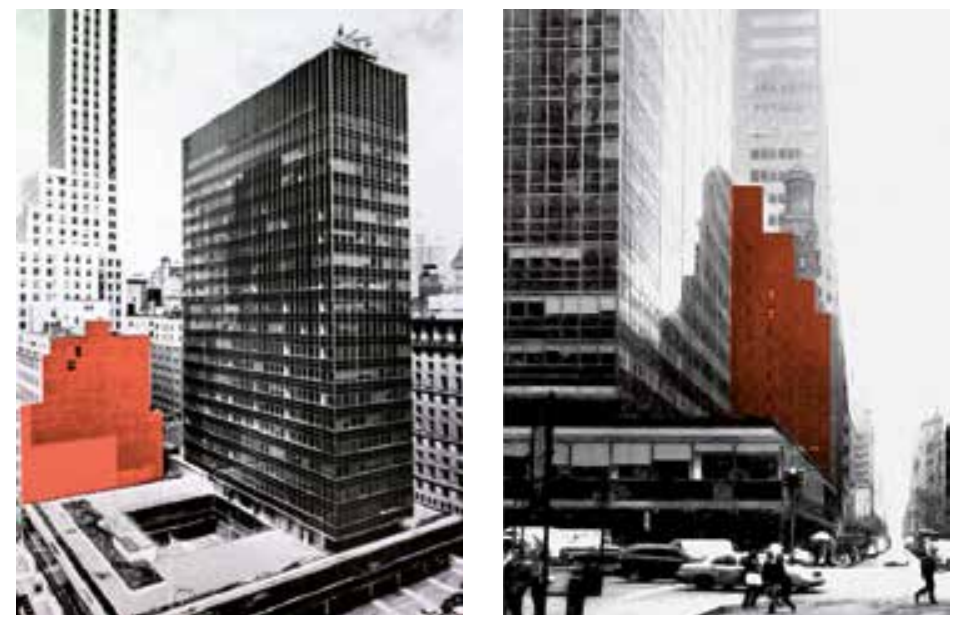

Fig. 4. Los testeros vistos de los edificios contiguos de la calle 53 y de la calle 54 (Hotel Elysee).

B. Parallel to Park Avenue and displaced toward the back of the site. If the piece had been pushed to the back, the image would have been reminiscent of the tower-platform designed by Nathanial A. Owings (Tomorrow's Office Building). This would have covered up the facades of the neighbouring buildings, (Fig. 4) but, because the site is L-shaped, the line of the boundary wall of the building on 53rd Street would not be aligned with the wall abutting the building on 54th Street. The problem here is that the vertical body would be displaced up to the site boundary facing 53rd Street, leaving a facade gap between the Hotel Elysee and the new project, thus creating an architectural inconsistency.

A further drawback would become evident when looking at the building from 53rd Street, because the meeting point between the Lever House tower -rising 24 stories- and the adjacent volume -a low-lying pyramid (developed as receding steps from the 10th floor upwards)- would lead to a rather forced architectural clash devoid of an appropriate spatial dialogue. (Fig. 5)

A further problem would have been the loss of sunlight and views from the interior at the lower levels of the tower owing to the lack of lateral clearance. Natalie de Blois explains how this solution was ruled out and compares it to the Seagram building: "If it had been designed using the same strategy as Mies's Seagram building, the solution would have been a poor one: the footprint of Lever House could only be one quarter of the site -the site wasn't that deep, either- if the building had been placed parallel to Park Avenue it would have been pretty pathetic". (9) 


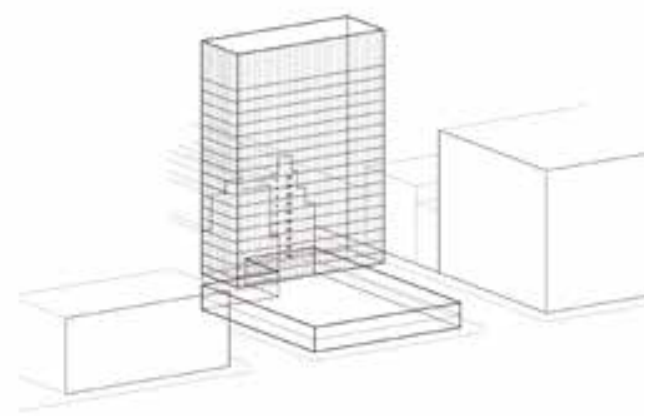

de la obra orientada a la calle 53, dejando un hueco en fachada entre el Hotel Elysee y la nueva intervención de inconsistente justificación arquitectónica.

Surgiría otro inconveniente al contemplar el proyecto desde la calle 53, ya que el encuentro entre la torre de la Lever House, de 24 plantas, y el volumen contiguo, de baja altura y esquema piramidal -se desarrolla de forma escalonada desde la décima planta-, provocaría un encuentro arquitectónico forzado y desprovisto de un diálogo espacial correcto. (Fig. 5) A ello se habría sumado el problema de la pérdida de luz y vistas desde el interior en las plantas inferiores de la torre, al no estar exentas. Natalie de Blois explica cómo se eludió esta solución, comparándola con el Seagram: "Si se hubiese diseñado con la misma estrategia que el edificio Seagram de Mies habría sido una mala solución, dado que la ocupación en planta sólo podía ser un cuarto de la superficie del solar y nuestro solar no era tan profundo como el de Mies, además de que si el edificio se hubiese colocado paralelo a Park Avenue, el resultado habría sido bastante patético". (9)

C. giro en ángulo recto a Park Avenue y ajuste a la línea de fachaDA DE LA CALLE 53. Si se hubiese girado la pieza en ángulo recto para ajustarla al lateral de la calle 53, (Fig. 6) se habría generado un problema de soleamiento, ya que la torre arrojaría sombra al cuerpo bajo de la plataforma.
Fig. 5. Hipótesis 2: pieza vertical paralela a Park Avenue y desplazada hasta el fondo de la parcela. Detalle del encuentro en la planta décima entre la pieza vertical y el edificio contiguo en la calle 53. (gráfico elaborado por los autores).

C. Right-angle rotation from Park Avenue and alignment with the FaÇAde line of 53Rd Street. If the piece had been rotated at a right angle to align it to 53rd Street, (Fig. 6) the problem would have been light, because the tower would keep the lower body of the platform in shadow.

As Bunshaft himself said in his interview with Betty J. Blum: "In architecture there's two things: seeing a lot of things and then knowing how to see them [...] An architect's trained in shades and shadows. When I look at something, I can see the shape of the shadow and what causes it". (10)

There would have been a 'visual thrust' issue rather like the one seen under hypothesis 1, but now directed toward the club: "The Racquet Club is across the street from Seagram and it's just south of Lever House. We did think about that building, and I think in a way this placing of the mass in that direction kind of played up against that. Of course, we didn't know what was going to happen on the other side, and the building was placed at the other end". (11)

D. Right-angle rotation from Park Avenue and alignment with the faÇade line of 54th Street. The tower could have been placed at the northern edge, aligned with the facade of 54th Street. (Fig. 7) This, however, would have involved abutment issues with another neighbouring building, the Hotel Elysee, [see figure 4] because the boundary walls consisted of receding steps. This would have detracted from the visual and architectural balance between the 
Como apuntaba Bunshaft en su entrevista con Betty J. Blum: "En la arquitectura hay que diferenciar entre dos cosas: ver un montón de edificios y luego saber cómo verlos [...] Un arquitecto o un artista ha entrenado y está capacitado en tonos y sombras. Cuando ve algo, puede ver la forma de la sombra y qué es lo que la causa”. (10)

Existiría un problema de 'vuelco visual' similar al observado en la primera hipótesis, pero ahora hacia el referido club: "Hay un edificio justo al sur de la Lever House, se trata del edificio Racquet Club, al otro lado del edificio Seagram. Pensábamos en ese edificio y la mejor manera de colocar el volumen de la torre sin que le perjudicase; no sabíamos lo que iba a ocurrir y el edificio se colocó en el otro extremo". (11)

D. giro en ángulo recto a Park Avenue y ajuste a la línea de faCHADA DE LA CALle 54. Podría haberse ubicado la torre en el borde norte, alineada con la fachada de la calle 54. (Fig. 7) Pero ello implicaría problemas de encuentro con otro edificio vecino, el Hotel Elysee, [ver figura 4] al existir muros medianeros escalonados. Además de provocar mermas en el equilibrio visual y arquitectónico entre la plataforma horizontal y la torre -a modo de 'pescante invertido'-, se sumaría el problema de las restricciones de la normativa, que permitían alcanzar sólo doce alturas si la fachada se proyectaba enrasada a línea de fachada. Como señalaba Bunshaft: "No podíamos enrasar la torre vertical con la calle 54 por las restricciones de la normativa; por tanto, al desplazarla hacia el interior podíamos llegar hasta el eje central de la parcela, pero no nos interesaba ya que queríamos huir de la simetría". (12)

E. RESULTADO FINAL. El cuerpo vertical de la Lever House adoptó finalmente una disposición lateral en la parcela, a veinte metros de la calle 54 desde su eje y a cuarenta metros desde éste hasta la calle 53, recurriendo a la asimetría como herramienta para conseguir el equilibrio volumétrico deseado. Bunshaft consideró que la silueta de los volúmenes del fondo 'escenográfico' no afectaría al resultado proyectual definitivo.
Fig. 6. Hipótesis 3: giro en ángulo recto a Park Avenue y pegada a línea de fachada de la calle 53. (gráfico elaborado por los autores).

Fig. 7. Hipótesis 4: pieza vertical perpendicular a Park Avenue y pegada a la línea de fachada de la calle 54 (gráfico elaborado por los autores).

Fig. 8. Resultado final de la posición de la pieza vertical de la Lever House (gráfico elaborado por los autores).

horizontal platform and the tower -by way of 'inverted jib'- and moreover, planning regulations would allow only twelve stories if the facade was flush with the streetfront.

In Bunshaft's own words: "[...] the location of the tower from left to right as you face it from Park Avenue, is set by the zoning to a degree. We couldn't have moved it farther north aesthetically because of the envelope. We could have moved it maybe to the middle, but that we didn't want. We wanted to have some asymmetry". (12)

E. FINAL RESULT. Finally, the vertical body of Lever House was positioned within the site laterally twenty metres from 54 th Street from its axis, and forty metres from the axis to 53rd Street: asymmetry was used as a tool to achieve the desired volumetric balance. Bunshaft felt that the silhouette of the 'scenographic' background volumes would not affect the final design result.

The final placement of the tower (Fig. 8) lent to the whole the desired architectural equilibrium by bringing into play an intelligent spatial dialogue with the environment. By rotating the tower at a right angle with respect to hypothetical initial position, the views from the interior were enhanced and created suggestive perspective backgrounds. (13) The internal distribution included open spaces graced with intense natural light, so releasing attractive visuals towards the adjacent streets and Park Avenue, on which two key players came onto the stage: Grand Central Station and the Pan Am Tower, designed by Gropius in 1963. (Fig. 9) 

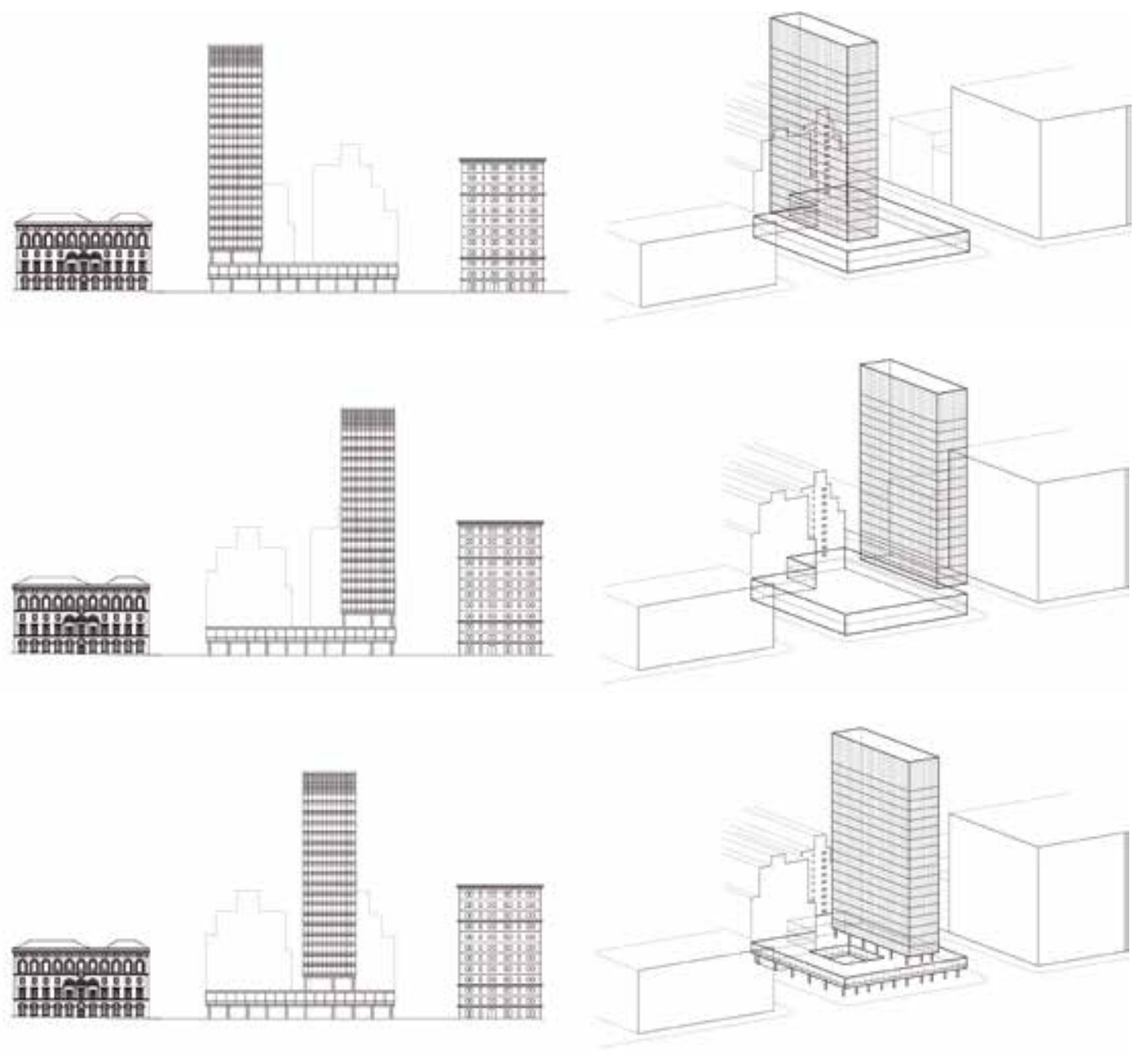

This dialogic-contextual strategy, through the disruption or discontinuity of the facade front using 'urban silences', projected the work as a whole as an orderly and spatially harmonious unit, springing from a self-consistent idea that was tightly linked to the various compositional features of the building in its totality.

Analogies with the Addition to the Albright Knox Art Gallery. In this other work, dated 1962, Bunshaft designed a large open courtyard on the ground floor connected to the existing building, while at the other end erecting a structure that rose by a further floor. This compositional method in some way parallels the one used in Lever House. (Fig. 10) A comparison of the two projects reveals a shared strategy: a dialogic approach to preexistents by means of 'urban silence'.

Four basic elements are in play: element is the pre-existing building (for Lever House, this was the Racquet and Tennis Club; here, it is the Albright Museum). At Lever House, the second element was the platform; at Albright Knox, the second platform is linked to the first element by means of topological and morphological strategies that rely on a closed and opaque horizontal piece. The third element embodies those pieces that emerge in both buildings: the tower at Lever House and the black glass prism at Albright Knox. (Fig. 11) Finally, the fourth element symbolises 'urban silence', (Fig. 12) which lies between the first and the third elements.

Volumetric Dematerialisation on the Lower Horizontal Plane. To characterise the Modern Movement with a rather broad brush, one might say that one of its features was that project results were to be conceived of as compositions of 
La posición definitiva de la torre (Fig. 8) otorgó al conjunto el anhelado equilibrio arquitectónico, activando un inteligente diálogo espacial con el entorno. Al girar en ángulo recto dicha torre desde su hipotética posición inicial, se enriquecieron las vistas desde el interior, provocando unos sugerentes fondos perspectivos. (13) La distribución interna incorporaría espacios abiertos con intensa iluminación natural, que liberarían atractivas visuales hacia las calles transversales y Park Avenue, donde entrarían en escena dos significativas piezas: Grand Central Station y la torre Pan Am, que diseñó Gropius en 1963. (Fig. 9)

Esta estrategia dialógico-contextual, a través de la ruptura o discontinuidad del frente de fachada mediante 'silencios urbanos' hizo que el conjunto se proyectarse como una unidad ordenada y espacialmente armónica, fruto de una ideación unitaria e indisociable de los diferentes elementos compositivos del edificio en su totalidad.

Analogías con la ampliación de la Albright Knox Art Gallery. En esta otra obra de 1962, Bunshaft proyectó un gran patio en planta baja, en la unión con el edificio antiguo, construyendo en el otro extremo una sala elevada en planta primera. La metodología compositiva empleada guarda paralelismos con la Lever House. (Fig. 10) El análisis contrastado entre ambas muestra la compartida estrategia proyectual: una aproximación dialógica a lo preexistente por medio del 'silencio urbano'. Intervienen cuatro elementos básicos: el primer elemento sería el edificio preexistente (en la Lever House, es el Racquet and Tennis Club; en el otro, el Museo Albright). El segundo elemento representa la plataforma (en la Lever House) y en el caso del Albright Knox, su segunda plataforma estaría unida al primer elemento mediante estrategias topológicas y morfológicas apoyadas en una pieza horizontal cerrada y opaca. El tercer elemento encarna las piezas que emergen en los dos edificios, la torre en la Lever House y el prisma vítreo de color negro en el Museo Albright Knox. (Fig. 11) Por último, el cuarto elemento simboliza el 'silencio urbano' (Fig. 12) que se posiciona entre el primer y el tercer elemento.
Fig.9. Vista de Park Avenue desde el interior de la Lever House.

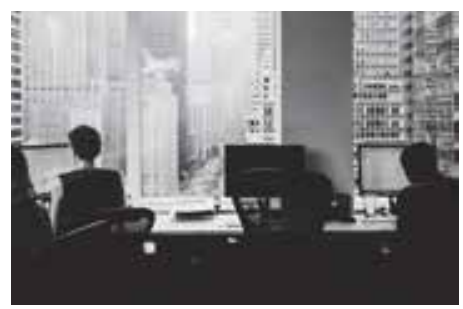

prisms, taking a purist approach that paid tribute to abstraction: this insight might be placed in relation to the treatment given to the ground floor and to how the lower plane is embedded in its context. The perceptual consequences of these strategies were a sense that architectural pieces somehow floated over the ground plane. This configuration could be interpreted as a 'dematerialised' solution. (14)

A similar behaviour of the lower horizontal plane with respect to the urban place began to be seen in the new tall buildings of Chicago and New York, where the ground floor came to be seen as the spatial connection with the city. This trend was incipient in Lakeshore Drive, designed by Mies in 1949, as it was in Lever House and the Seagram Building; a further exemplar is the solution designed by Bunshaft for the Pepsi-Cola Company.

All these formulations rest on the same design premises for the ground floor: two de-link the envelope of the structure, so as to displace the planes of the enclosure from the facade line and cause the transition from the ground level to the new building to become diluted within the visual dialogue. The setting-back on the lower plane meant that the resulting exterior space belonged as much to the city as to the building itself. The wellspring of the architectural piece, therefore, arose not only from morphological and aesthetic processes but also from pure function. To return to Arnheim: "As long as the base of a building is in contact with the ground, the need for visual breathing space does not apply to its bottom. However, when it is conceived as a mass suspended above the ground and resting on columns, piers, arches, or pilots, a proper air space is required for this additional dimension as well". (15) We must nonetheless underscore a difference between Lever House and the Seagram Building. In Mies's work, (Fig. 13) the strategy is to separate the entire building 
Desmaterialización volumétrica en el plano horizontal inferior. Sintetizando alguna característica del Movimiento Moderno, cabe entender que propugnaba resultados proyectuales como composiciones de prismas de corte purista y tributarios de la abstracción; una cuestión relacionable con el tratamiento de la planta baja y del engarce del plano inferior con su contexto. Las consecuencias perceptivas de estas estrategias implicaban la impresión de que las piezas arquitectónicas llegaban a 'flotar' sobre el plano del suelo; configuración que podría interpretarse en clave de solución 'desmaterializada'. (14) Semejante comportamiento del plano horizontal inferior con respecto al lugar urbano comenzó a reflejarse en los nuevos edificios en altura de Chicago y Nueva York, planteando la planta baja como conexión espacial con la ciudad. Esto resulta incipiente en el caso de Lake Shore Drive, ideado por Mies en 1949, así como en la Lever House y el Seagram; también es un buen ejemplo la solución que realiza Bunshaft para la empresa Pepsi Cola.

Estas formulaciones responden a las mismas premisas proyectuales para la planta baja: desligar la piel de la estructura, quedando desplazados de la línea de fachada los planos del cerramiento y consiguiendo que el elemento de transición entre el nivel del suelo y el nuevo edificio se diluya en el diálogo visual. El retranqueo en el plano inferior suponía que el espacio exterior resultante pertenecía tanto a la ciudad como al edificio. Así, el arranque de la pieza arquitectónica se generaba, no sólo mediante procesos morfológico-estéticos, sino también funcionales. Retomando las visiones de Arnheim: "Mientras la base de un edificio esté en contacto con el suelo, la necesidad de espacio visual 'respirable' no afecta a su parte inferior. Sin embargo, cuando es concebido como una masa suspendida sobre el suelo (descansando sobre columnas, pilotes o arcos), se requiere un adecuado ámbito aéreo para que cristalice esta dimensión adicional". (15) Procede aquí subrayar una diferencia entre la Lever House y el Seagram. En el caso de la obra de Mies, (Fig. 13) la estrategia es separar todo el edificio de Park Avenue para ganar perspectiva y provocar curiosidad visual, al intercalar un vacío en la secuencia urbana, que rompe la rítmica sucesión de fachadas alineadas del contexto. El cerramiento de vi-
Fig.10. Análisis comparativo entre la Lever House y el Albright Knox: el 'silencio urbano' entre lo nuevo y lo viejo (gráfico elaborado por los autores).

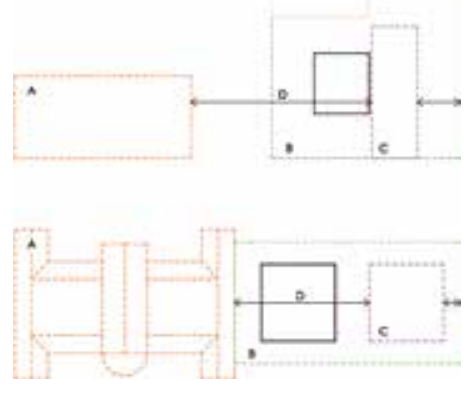

Fig. 11. Imagen desde el exterior de la Albright Knox Gallery.

Fig. 12. Esquema del 'silencio urbano' entre lo nuevo y lo viejo. (gráfico elaborado por los autores).
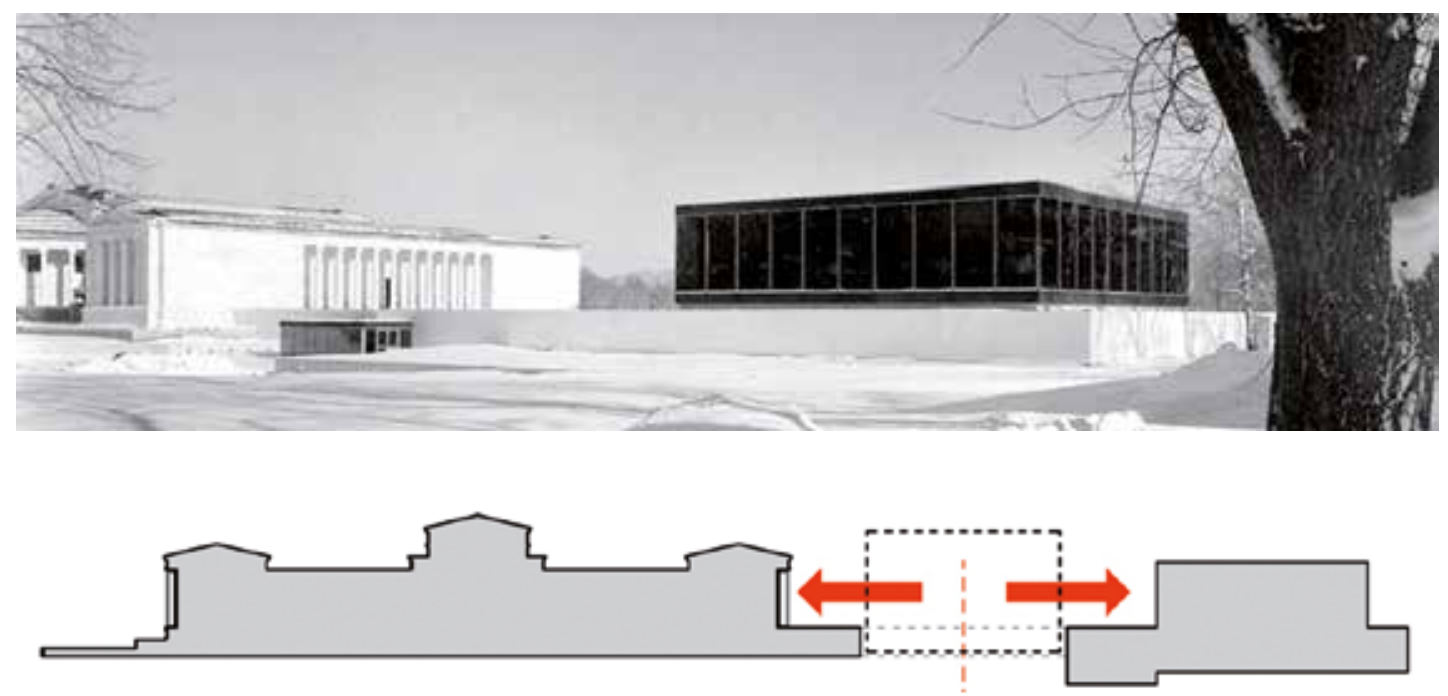
drio en planta baja se retranquea, dejando un paso cubierto como corredor en todo el perímetro.

En cambio, el planteamiento de la Lever House para su unión con el suelo (Fig. 14) es muy diferente: se deja gran parte de la planta baja libre, configurando toda la fachada del primer nivel continúa sobre el perímetro de la parcela. De este modo, la pieza construida presenta un carácter más reconocible en términos topológicos y geométricos. Semejante solución resulta de cierta complejidad, pero mantiene el equilibrio entre sus componentes. El plano de vidrio se traslada hasta la base de la torre, creando dos espacios exteriores: uno grande, a modo de plaza cubierta y abierta mediante un patio y otro ámbito cubierto que provoca que la estrecha calle 54 se ensanche. Ambos espacios exteriores activan diálogos visuales, ya que el hall de entrada de la torre contiene planos de vidrio de suelo a techo; los elementos cerrados son adyacentes a la medianera de los edificios vecinos para dejar el resto de la parcela abierta.

El proyecto para Pepsi Cola (Fig. 15) se resuelve como híbrido entre las soluciones anteriores. Por un lado, existe un desplazamiento general del edificio hacia el interior de la parcela, creando un espacio exterior ajardinado como huella que da testimonio de la memoria formal de la parcela, (16) pero también cristaliza una relación visual entre las dos calles, desmaterializando la esquina con planos de vidrio, que se trasladan media crujía hacia el interior, lo que genera percepciones visuales como flotación, desunión, desmaterialización o transparencia.

En clave de experiencia dialógica, los ámbitos que circundan los edificios no se interiorizan como 'vacíos. Por el contrario, están ocupados por fuerzas visuales emanadas de las estructuras arquitectónicas y determinadas en sus propiedades particulares por el tamaño y forma de sus núcleos generadores. Tales fuerzas visuales no se entienden como líneas de energía aisladas, sino como "componentes de campos perceptivos que rodean los edificios y que son también activos en sus espacios interiores", (17) como describe Arnheim.

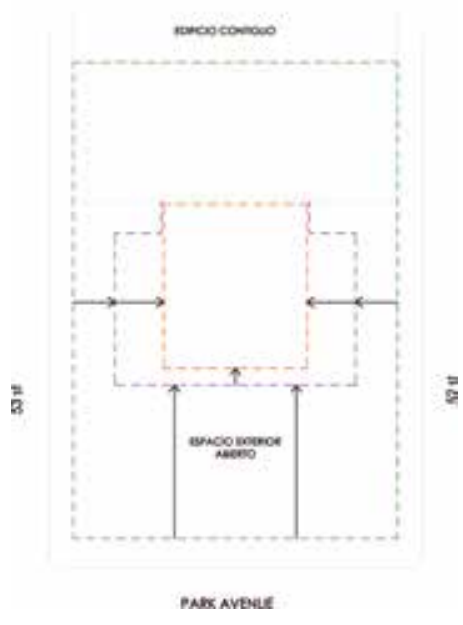

SEAGRAM 1954-1958

Fig. 13. Esquema del Seagram sobre el vacío urbano en el nivel de la planta baja (gráfico elaborado por los autores).

from Park Avenue so as to gain perspective and create visual stimulus by inserting a vacuum in the urban sequence that disrupts the contextual succession of aligned facades. The glass enclosure of the ground floor is set back, leaving a covered walkway as a corridor all around the perimeter.

However, for Lever House a very different strategy was used for its juncture with the ground: (Fig. 14) a large portion of the ground floor is left open, configuring the entire facade of the first level as a continuum around the perimeter of the site. The built structure is hence more recognisable in topological and geometric terms. The solution is somewhat complex, but maintains a balance among its components. The glass plane is taken down to the base of the tower to create two exterior spaces: one large one in the form of a covered plaza opening out to a patio and another covered space that widens the otherwise narrow 54th Street. Both these exterior spaces call visual dialogues into being, since the entrance hall of the tower contains floor-to-ceiling panes of glass; the closed elements are adjacent to the walls abutting the neighbouring buildings so as to leave the rest of the site open.

The project design for Pepsi-Cola (Fig. 15) is a hybrid of the solutions discussed earlier. First, there is a general displacement of the building toward the interior of the site, creating a garden outdoor space as an imprint testifying to the formal memory of the place. (16) But the design also crystallises a visual relationship between the two streets, dematerialising the corner with glass planes that extend halfway along the open space toward the interior, thus generating visual perceptions such as flotation, disjunction, dematerialisation and transparency. 


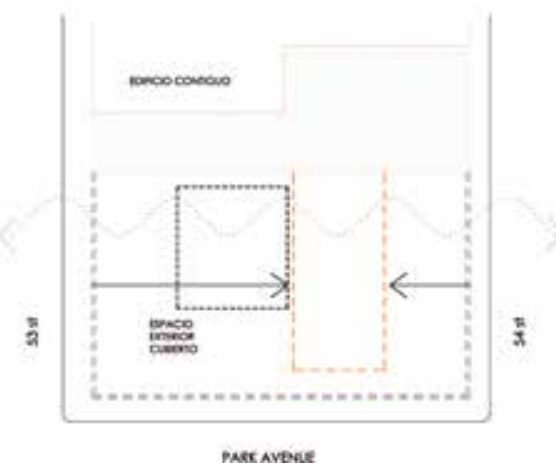

LEVER HOUSE 1952

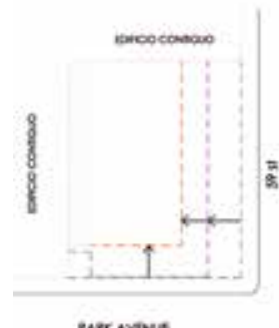

EDIFICIO PEPSICOLA 1959

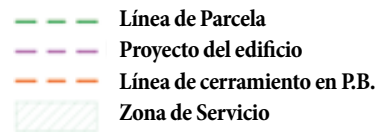

Figs. 14 y 15. Análisis comparativo entre la Lever House y el Edificio Pepsi Cola sobre el vacío urbano en el plano horizontal inferior (gráfico elaborado por los autores).

In terms of the dialogic experience, the spaces surrounding the buildings are not interiorised as 'empty'. Rather, they are inhabited by visual forces that spring from the architectural structures, shaped in their specific features by the size and form of the cores from which they flow. Those visual forces are not isolated lines of energy, but in the words of Arnheim, "[...]components of perceptual fields that surround buildings and are also active in interior spaces" (17)

A further Comment: the Influence of Planning Regulations. Both Mies's Seagram Building and Bunshaft's works were built before 1961, when planning regulations still came under the aegis of the 1916 Zoning Resolution. (18) The projects were of course compliant with the prevailing resolution; but by virtue of it, they involved the creation of public spaces in the form of loci for an interrelationship between the city and the building. And they had an influence on a later change of planning laws -a new zoning resolution was passed in December 1961 (C5-3), (19) which permitted taller buildings in response to the emergence of spaces of this kind. 


\section{NOTAS}

1. ARNHEIM, Rudolf. La forma visual en la Arquitectura. Barcelona: Gustavo Gili, 2001. p. 19.

2. MORAZA, Juan Luis; CUESTA, Salomé. El Arte como criterio de excelencia. Campus de Excelencia Internacional. Madrid: Ministerio de Educación, 2010. p. 9.

3. MARTÍ, Carlos. Silencios elocuentes. Barcelona: Universitat Politècnica de Catalunya, 1999.

4. MUNTAÑOLA, Josep. 'Arquitectura, Educación y dialogía social'. Revista Española de Pedagogía. 2004. Año LXII, n. 228. pp. 221-228.

5. ARNHEIM, Rudolf. La forma visual en la Arquitectura. Opus cit. p. 21. 6. KRINSKY, Carol. Gordon Bunshaft of Skidmore, Owings \& Merrill. New York: The Architectural History Foundation, 1988. pp. 21-24.

7. El equilibrio visual y compositivo entre los volúmenes que componen el edificio, torre-plataforma, responde también a la relación implícita entre las partes mediante el 'silencio urbano.' "Al incluir ausencias en las superficies con el objeto de enfatizar y poner en valor jerárquico determinados puntos a destacar frente al resto [...] reduciendo e intensificando el problema formal mediante la supresión de fragmentos de los volúmenes, se resuelve el encuentro de cada una de las piezas del conjunto edificado mediante la manifestación de un vacío, una separación, un silencio. Cada elemento se distingue por aparentar no estar en contacto directo con ningún otro, su unión es aquella que se manifiesta por la ausencia de materia [...] perforación vacía, oscurecida, que ponía en eficaz tensión la totalidad". DE MIGUEL, Sergio. Donde se rompen las nubes: La Lever House, Nueva York 1950. Tesis doctoral, Universidad Politécnica de Madrid, 2015. p. 194.

8. BLUM, Betty J. Oral History of Gordon Bunshaft. Chicago: Department of Architecture. The Art lnstitute of Chicago, 1990. pp. 163-164. Traducción del autor.

9. BLUM, Betty J. Oral History of Natalie de Blois. Chicago: Department of Architecture. The Art lnstitute of Chicago, 2004. p. 46. Traducción del autor. 10. BLUM, Betty J. Oral History of Gordon Bunshaft. Opus cit. p. 62. Traducción del autor.

11. BLUM, Betty J. Oral History of Natalie de Blois. Opus cit. p. 47. Traducción del autor.

12. BLUM, Betty J. Oral History of Gordon Bunshaft. Opus cit. p. 161. Traducción del autor.

13. Como cita Le Corbusier en su libro La ciudad del futuro de 1924, sobre el ángulo recto: "El ángulo recto es como la integral de las fuerzas que mantienen al mundo en equilibrio".

14. GIEDION, Siegfried. Espacio, tiempo y arquitectura. Barcelona: Científico-Médica, 1955. p. 514-515.

15. ARNHEIM, Rudolf. La forma visual en la Arquitectura. Opus cit. p. 27. 16. PARGA VAZQUEZ, Andrea. 30'0M x 37'5M New York Gordon Bunshaft. Trabajo fin de Máster (inédito). Universitat Politècnica de Catalunya, 2011. p. 27.

17. ARNHEIM, Rudolf. La forma visual en la Arquitectura. Opus cit. p. 27. 18. Véase el apartado 'Discontinuidad en la trama urbana de Manhattan' en la guía titulada ¿Qué es la zonificación? The Center for Urban Pedagogy. Envisioning Development. Guía n. 2. Ed. De la ciudad de Nueva York. 19. Zoning Maps and Resolutions. Effective December 15, 1961. Article III. 'Commercial District Regulations'. Chapter 1. Statement of Legislative Intent C5, Restricted central commercial districts. p. 102.
NOTES

1. ARNHEIM, Rudolf. La forma visual en la Arquitectura. Barcelona: Gustavo Gili, 2001. p. 19.

2. MORAZA, Juan Luis; CUESTA, Salomé. El Arte como criterio de excelencia. Campus de Excelencia Internacional. Madrid: Ministerio de Educación, 2010. p. 9.

3. MARTÍ, Carlos. Silencios elocuentes. Barcelona: Universitat Politècnica de Catalunya, 1999.

4. MUNTAÑOLA, Josep. 'Arquitectura, Educación y dialogía social'. Revista Española de Pedagogía. 2004. Año LXII, n. 228. pp. 221-228.

5. ARNHEIM, Rudolf. La forma visual en la Arquitectura. Opus. cit. p. 21. 6. KRINSKY, Carol. Gordon Bunshaft of Skidmore, Owings \& Merrill. New York: The Architectural History Foundation, 1988. pp. 21-24.

7.The visual and compositional balance among the volumes of the building, tower-platform, also reflects the implicit relationship among the different parts by means of 'urban silence': "By including absences in the surfaces to emphasise and raise the hierarchical value of certain points to be highlighted as against the rest $[. .$.$] and reducing and intensifying the$ formal problem by suppressing fragments of volumes, the conjunction of each of the pieces of the built whole is resolved through the manifestation of a vacuum, a separation, a silence. Each element is made distinct by appearing not to be in direct contact with any other element; its union is manifested by the absence of matter [...] an empty and obscured perforation that places the totality in an effective state of tension". DE MIGUEL, Sergio. Donde se rompen las nubes: La Lever House, Nueva York 1950. Doctoral Thesis, Universidad Politécnica de Madrid, 2015. p. 194. 8. BLUM, Betty J. Oral History of Gordon Bunshaft. Chicago: Department of Architecture. The Art lnstitute of Chicago, 1990. pp. 163-164. Translation by the author.

9. BLUM, Betty J. Oral History of Natalie de Blois. Chicago: Department of Architecture. The Art lnstitute of Chicago, 2004. p. 46. Translation by the author.

10. BLUM, Betty J. Oral History of Gordon Bunshaft. Opus. cit. p. 62.

Translation by the author.

11. BLUM, Betty J. Oral History of Natalie de Blois. Opus. cit. p. 47.

Translation by the author

12. BLUM, Betty J. Oral History of Gordon Bunshaft. Opus. cit. p. 161.

Translation by the author

13. As said by Le Corbusier in his 1924 book The City of Future about the right angle: "The right angle is like the integral of the forces that keep the world in equilibrium”.

14. GIEDION, Siegfried. Espacio, tiempo y arquitectura. Barcelona: Científico-Médica, 1955. p. 514-515.

15. ARNHEIM, Rudolf. La forma visual en la Arquitectura. Opus. cit. p. 27. 16. PARGA VAZQUEZ, Andrea. 30'0M $x$ 37'5M New York Gordon Bunshaft. Unpublishede master's dissertation, Universitat Politècnica de Catalunya, 2011. p. 27.

17. ARNHEIM, Rudolf. The Visual Form of Architecture. Opus cit. p. 27. 18. See the interesting guide ¿Qué es la zonificación? The Center for Urban Pedagogy. Envisioning Development. Guide n. 2. Ed. New York City See the section 'Discontinuity in the Manhattan urban grid' (177).

19. Zoning Maps and Resolutions. Effective December 15, 1961. Article III. 'Commercial District Regulations'. Chapter 1. Statement of Legislative Intent C5, Restricted central commercial districts. p. 102. 


\section{REFERENCIAS}

ADAMS, Nicholas. Skidmore, Owings \& Merrill. SOM dal 1936. Milán: Electa, 2006.

ARNHEIM, Rudolf. La Forma visual en la Arquitectura. Barcelona: Gustavo Gili, 2001.

BLUM, J. Betty. Oral History of Gordon Bunshaft. Chicago: Department of Architecture. The Art lnstitute of Chicago, 1990.

BLUM, J. Betty. Oral History of Natalie de Blois. Chicago: Department of Architecture. The Art lnstitute of Chicago, 2004.

CATTANI, Rudivan. Torres que rematan manzanas. Tesis doctoral, Universitat Politècnica de Catalunya, ETSAB, 2013. Disponible en: [http://hdl. handle.net/10803/126621].

DE MIGUEL, Sergio. La Lever House, New York. Madrid: Cuadernos de Proyectos Arquitectónicos, 2012.

DE MIGUEL GARCÍA, Sergio. Donde se rompen las nubes: La Lever House, Nueva York 1950. Tesis doctoral, Universidad Politécnica de Madrid, 2015. Disponible en: [http://oa.upm.es/40369/].

GIEDION, Siegfried. Espacio, tiempo y Arquitectura. Barcelona: Científico- Médica, 1955.

KRINSKY, Carol. Gordon Bunshaft of Skidmore, Owings \& Merrill. Nueva York: The Architectural History Foundation, 1988.

MARTÍ, Carlos. Silencios elocuentes. Barcelona: Universitat Politècnica de Catalunya, 1999.

MORAZA, Juan Luis; CUESTA, Salomé. El Arte como criterio de excelencia. Campus de Excelencia Internacional. Madrid: Ministerio de Educación, 2010. MUNTAÑOLA, Josep. 'Arquitectura, Educación y dialogía social'. Revista Española de Pedagogía. 2004. Año LXII, n. 228.

PARGA VAZQUEZ, Andrea. 30'0M x 37’5M New York Gordon Bunshaft. Trabajo Fin de Master inédito, Universitat Politècnica de Catalunya, 2011.

SUÁREZ MANSILLA, Luis. Estrategias y Efectos de Escala. Un desafío moderno, 1943.1966. Tesis doctoral, Universidad de Navarra, ETSAP, 2010. Disponible en: [http://fundacion.arquia.es].

SICA PALERMO, Nicolás. Forma y tectonicidad: estructura y prefabricación en la obra de Gordon Bunshaft. Tesis doctoral, Universitat Politècnica de Catalunya, ETSAB, 2012. Disponible en: [http://hdl.handle.net/10803/113783].

\section{REFERENCES}

ADAMS, Nicholas. Skidmore, Owings \& Merrill. SOM dal 1936. Milano: Electa, 2006.

ARNHEIM, Rudolf. La Forma visual en la Arquitectura. Barcelona: Gustavo Gili, 2001.

BLUM, J. Betty. Oral History of Gordon Bunshaft. Chicago: Department of Architecture. The Art lnstitute of Chicago, 1990.

BLUM, J. Betty. Oral History of Natalie de Blois. Chicago: Department of Architecture. The Art lnstitute of Chicago, 2004.

CATTANI, Rudivan. Torres que rematan manzanas. Doctoral Thesis, Universitat Politècnica de Catalunya, ETSAB, 2013. Available at: [http://hdl.

handle.net/10803/126621].

DE MIGUEL, Sergio. La Lever House, New York. Madrid: Cuadernos de Proyectos Arquitectónicos, 2012.

DE MIGUEL GARCÍA, Sergio. Donde se rompen las nubes: La Lever House, Nueva York 1950. Doctoral Thesis, Universidad Politécnica de Madrid, 2015. Available at: [http://oa.upm.es/40369/].

GIEDION, Siegfried. Espacio, tiempo y Arquitectura. Barcelona: Científico- Médica, 1955.

KRINSKY, Carol. Gordon Bunshaft of Skidmore, Owings \& Merrill. New York: The Architectural History Foundation, 1988.

MARTÍ, Carlos. Silencios elocuentes. Barcelona: Universitat Politècnica de Catalunya, 1999.

MORAZA, Juan Luis; CUESTA, Salomé. El Arte como criterio de excelencia. Campus de Excelencia Internacional. Madrid: Ministerio de Educación, 2010. MUNTAÑOLA, Josep. 'Arquitectura, Educación y dialogía social'. Revista Española de Pedagogía. 2004. Año LXII, n. 228.

PARGA VAZQUEZ, Andrea. 30'0M x 37'5M New York Gordon Bunshaft. Master Project (unpublished), Universitat Politècnica de Catalunya, 2011.

SUÁREZ MANSILLA, Luis. Estrategias y Efectos de Escala. Un desafío moderno, 1943.1966. Doctoral Thesis, Universidad de Navarra, ETSAP, 2010. Disponible en: [http://fundacion.arquia.es].

SICA PALERMO, Nicolás. Forma y tectonicidad: estructura y prefabricación en la obra de Gordon Bunshaft. Doctoral Thesis, Universitat Politècnica de Catalunya, ETSAB, 2012. Available at: [http://hdl.handle.net/10803/113783]

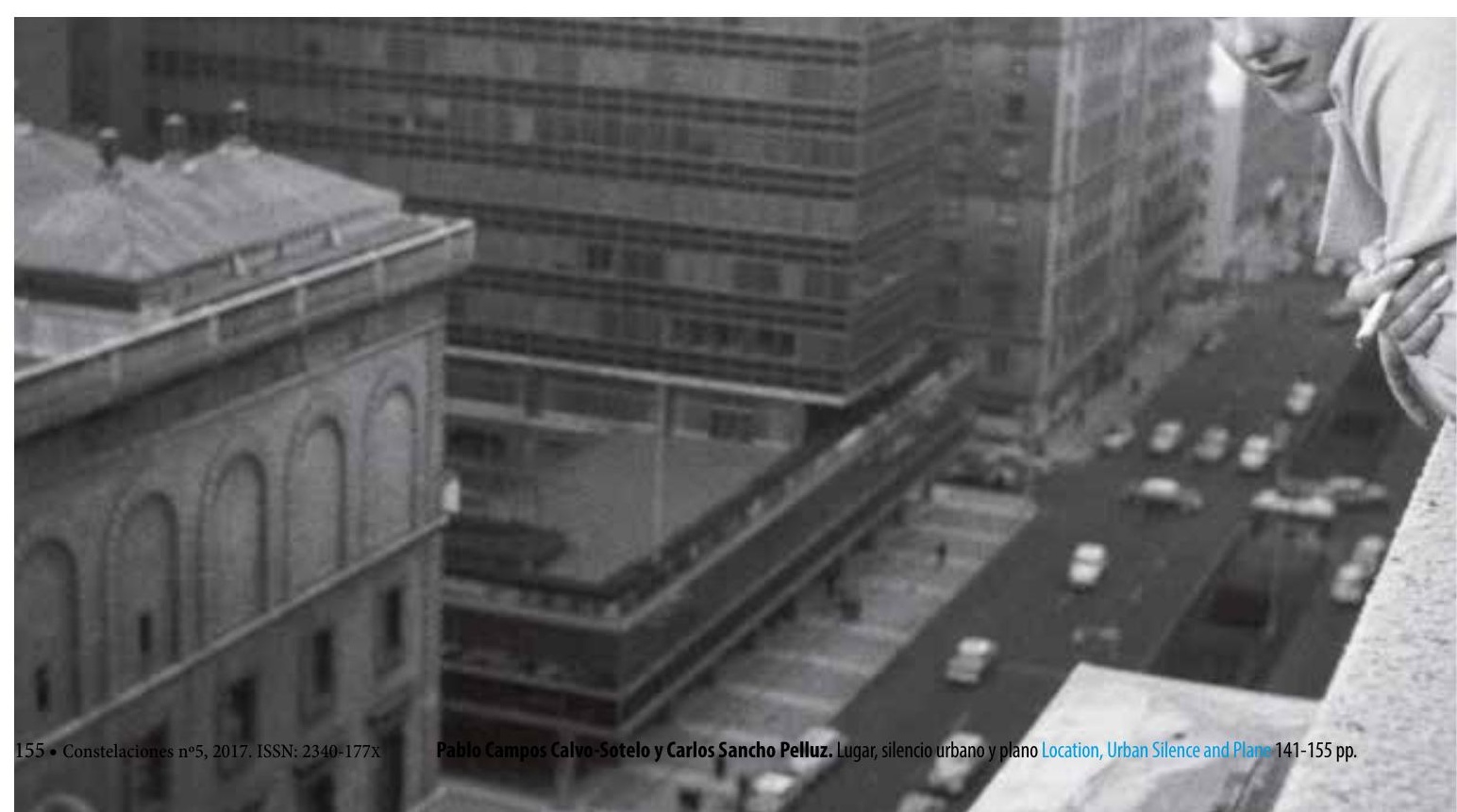

